\title{
Estimation of the postmortem interval based on the human decomposition process
}

Citation for published version (APA):

Gelderman, H. T., Kruiver, C. A., Oostra, R. J., Zeegers, M. P., \& Duijst, W. L. J. M. (2019). Estimation of the postmortem interval based on the human decomposition process. Journal of Forensic and Legal Medicine, 61, 122-127. https://doi.org/10.1016/j.jflm.2018.12.004

Document status and date:

Published: 01/02/2019

DOI:

10.1016/j.jflm.2018.12.004

Document Version:

Publisher's PDF, also known as Version of record

Document license:

Taverne

Please check the document version of this publication:

- A submitted manuscript is the version of the article upon submission and before peer-review. There can be important differences between the submitted version and the official published version of record.

People interested in the research are advised to contact the author for the final version of the publication, or visit the DOI to the publisher's website.

- The final author version and the galley proof are versions of the publication after peer review.

- The final published version features the final layout of the paper including the volume, issue and page numbers.

Link to publication

\footnotetext{
General rights rights.

- You may freely distribute the URL identifying the publication in the public portal. please follow below link for the End User Agreement:

www.umlib.nl/taverne-license

Take down policy

If you believe that this document breaches copyright please contact us at:

repository@maastrichtuniversity.nl

providing details and we will investigate your claim.
}

Copyright and moral rights for the publications made accessible in the public portal are retained by the authors and/or other copyright owners and it is a condition of accessing publications that users recognise and abide by the legal requirements associated with these

- Users may download and print one copy of any publication from the public portal for the purpose of private study or research.

- You may not further distribute the material or use it for any profit-making activity or commercial gain

If the publication is distributed under the terms of Article $25 \mathrm{fa}$ of the Dutch Copyright Act, indicated by the "Taverne" license above, 
Research Paper

\title{
Estimation of the postmortem interval based on the human decomposition process
}

\author{
H.T. Gelderman ${ }^{\mathrm{a}, \mathrm{b}, \mathrm{c}, \mathrm{d}, *}$, C.A. Kruiver ${ }^{\mathrm{e}}$, R.J. Oostra ${ }^{\mathrm{f}}$, M.P. Zeegers ${ }^{g}$, W.L.J.M. Duijst ${ }^{\mathrm{h}, \mathrm{i}}$ \\ ${ }^{\text {a }}$ Public Health Service IJsselland, Zwolle, the Netherlands \\ ${ }^{\mathrm{b}}$ Ars Cogniscendi Centre for Legal and Forensic medicine, Wezep, the Netherlands \\ ${ }^{\mathrm{c}}$ Maastricht University, Faculty of Law and Criminology, Maastricht, the Netherlands \\ ${ }^{\mathrm{d}}$ Academic Medical Center, University of Amsterdam, Amsterdam, the Netherlands \\ ${ }^{\mathrm{e}}$ Utrecht University, Utrecht, the Netherlands \\ ${ }_{\mathrm{f}}^{\mathrm{f}}$ Professor of Clinical and Comparative Morphology, Department of Medical Biology, Section Clinical Anatomy \& Embryology, Academic Medical Center, University of \\ Amsterdam, Amsterdam, the Netherlands \\ ${ }^{\mathrm{g}}$ Professor of Complex Genetics and Epidemiology and Forensic Epidemiologist, Care and Public Health Institute, Maastricht University, Maastricht, the Netherlands \\ ${ }^{\mathrm{h}}$ Professor of Forensic Medicine and Health-criminal Law, Maastricht University, the Netherlands \\ ${ }^{i}$ Public Health Service IJsselland, Zwolle, the Netherlands
}

\section{A R T I C L E I N F O}

\section{Presented cases}

Keywords:

Postmortem interval

Time since death

Decomposition

Human taphonomy

Dutch court

\begin{abstract}
A B S T R A C T
Postmortem interval (PMI) estimations which are used as evidence in Dutch court are sometimes solely based on the experience of the forensic physician without a scientific background. The aim of this study was to investigate the degree of agreement between forensic physicians and their PMI estimations.

Fifteen cases were selected from 1534 external postmortem investigations. Photographs of the human remains were presented to 89 forensic physicians in the Netherlands with the instruction to estimate the PMI based on their experience, knowing the remains were found indoors and in which season. Data analysis was conducted by using an interclass correlation (ICC) and Spearman's rank correlation coefficient.

This study shows a poor correlation (ICC $=0.254$ ) between the PMI estimations of the 89 forensic physicians. It is therefore not advised that PMI estimations based on experience be used as evidence in court.
\end{abstract}

\section{Introduction}

When a deceased person is found, there is always the question 'what is the time of death?'. A reliable, fast and well-grounded estimation of the postmortem interval (PMI) is of great importance for the timeline and the reconstruction of the events surrounding death. The PMI plays a major role in criminal investigations. ${ }^{1}$

Two processes are responsible for the decomposition process: autolysis (tissue decay by enzymatic degradation processes) and putrefaction (tissue decay by bacterial activity). Both processes begin immediately after death. In the initial stage after death, livor mortis, rigor mortis and algor mortis occur. Decomposition becomes externally visible as a blue-green skin discoloration, often starting in the right lower abdomen. Hereafter, the entire abdomen, thorax and often the upper parts of the arms and legs are green to green-red or deep purple to black. Epidermolysis occurs and blisters appear. The abdomen increases in size because of the gas formation in the intestines. At some point in the decomposition process, the gasses are released and the tissue caves in. This gives the eyes, throat and abdominal cavity a hollow appearance. ${ }^{2}$ Due to dehydration and draining of bodily fluids, the skin dries and gets a leathery appearance with discoloration and darkening of the skin. The skin becomes hard, contracts tightly around the bones and forms a shell over the body. This usually starts at the distal parts of the extremities or the ears, nose and mouth. ${ }^{2,3}$ As the decomposition process advances, skeletal parts are exposed. In specific circumstances, for example under warm conditions and in dry air, mummification can occur. ${ }^{4}$ Adipocere formation may happen when a body resides in an alkaline and anaerobe surrounding e.g. in (ground) water. $^{4}$

There is great variation in the time it takes for these processes to occur due to intrinsic and extrinsic factors, the effects of which accumulate over time, often in a non-constant way. ${ }^{4,5}$ Intrinsic factors are variables concerning the human remains themselves, for example cause of death, ${ }^{6}$ wounds or trauma ${ }^{6-8}$ and bodyweight. ${ }^{7,9-14}$ Extrinsic factors

\footnotetext{
* Corresponding author. Public Health Service IJsselland, Zeven Alleetjes 1, 8011 CV, Zwolle, the Netherlands.

E-mail addresses: tgelderman@hotmail.com (H.T. Gelderman), charissakruiver@hotmail.com (C.A. Kruiver), r.j.oostra@amc.uva.nl (R.J. Oostra), m.zeegers@maastrichtuniversity.nl (M.P. Zeegers), ackenniscentrum.nl@gmail.com (W.L.J.M. Duijst).
} 
that influence the rate and pattern of decomposition, and hence the actual PMI, are for example, air humidity, ${ }^{6}$ ambient temperature, ${ }^{2}$ oxygen level, ${ }^{5}$ degree of exposure to sunlight, ${ }^{5}$ body coverage, ${ }^{11,15,16}$ insect activity ${ }^{14}$ and subsoil parameters (for example, structure and composition, with the body being either buried or above ground). ${ }^{17-19}$

Since, due to these factors, the decomposition process is different for each set of human remains, advanced decomposition stages may be seen within a few hours after death ${ }^{20}$ or may not be seen after weeks. ${ }^{4}$ This makes PMI estimations increasingly unreliable as time proceeds. ${ }^{12}$

In the initial stage (hours after death), determining the algor mortis, ${ }^{21-23}$ rigor mortis ${ }^{4}$ and livor mortis, ${ }^{4,5}$ electrical or mechanical excitability of the biceps or facial muscles ${ }^{24,25}$ and the potassium concentration in the eye are usable methods. ${ }^{26-28}$ When a body is in or beyond the putrefaction stage, these methods can no longer be used. Therefore, other methods can be used to estimate the PMI for human remains found on land, for example Megyesi's Total Body Score (TBS), ${ }^{2}$ Gelderman's Total Decomposition Score (TDS), ${ }^{29}$ entomology, ${ }^{5,30-32}$ volatile fatty acids in soil ${ }^{33,34}$ and ATP (Adenosine Triphosphate) determination from the brain, liver, spleen, kidney and muscle. ${ }^{35-37}$ The former two methods are decomposition scoring methods which describe the decomposition process. With these methods, the PMI can be estimated using the accumulated degree days (ADD). The methods differ, however, since Megyesi put the phenomena in a rigid order, while some phenomena occur in the same stage. ${ }^{29}$ Gelderman's TDS takes this into account. The TDS is a validated decomposition score and can be applied to the human remains with separate scores for the face and neck, the body and the limbs. Six decomposition stadia are discerned with corresponding scores, with a lowest score of one (no visible changes) and the highest of six (complete skeletonization). The TDS represents the sum of the Facial Decomposition Score (FDS), the Body Decomposition Score (BDS) and the Limbs Decomposition Score (LDS). The stages of decomposition were derived from an extensive literature study. ${ }^{29}$

In the Netherlands, there is another method which is used in practice. Forensic physicians view the human remains and, based on their experience, estimate the PMI. A validated decomposition scoring method is not used. These estimations are allowed as evidence in Dutch court. ${ }^{38}$ In the Netherlands, forensic physicians perform external postmortem investigations and do not perform autopsies.

The main question of the study presented here is whether the PMI estimations made by the forensic physicians are sufficiently consistent to be used in Dutch court. Is there agreement between the estimations of the PMI by the forensic physicians based on the exterior inspection of human remains? We previously conducted a pilot study in which ten experienced forensic physicians estimated the PMI for fifteen human remains that were in an advanced state of decomposion. ${ }^{39}$ The results showed that the estimations may not be sufficiently consistent to be used in court. In the present study, the number of participating forensic physicians was expanded from 10 to 89. Furthermore, it was investigated whether the number of years of experience influences the extent of the agreement between the forensic physicians.

\section{Material and methods}

In this experimental research, 89 forensic physicians were asked to estimate the postmortem interval. They were given 15 cases in which the bodies were in an advanced state of decomposition, corresponding with Megyesi's TBS $\geq 9$ and Gelderman's TDS $\geq 9$.

\subsection{Forensic physicians}

There are about 250 forensic physicians in the Netherlands. Eightysix forensic physicians participated in this study. Four participants were excluded because they gave two PMI categories per case and two participants were excluded because they were still in training to become a forensic physician. Ten forensic physicians participated in the pilot study. ${ }^{39}$ These data, except for one anonymous participant, were included as well since the study design was identical to the present one. The total sample size used in the spread analysis is 89 forensic physicians. The research was conducted in several plenary sessions at various locations. A list of names of the participants was kept to avoid any duplicate data. The survey was taken anonymously. Five forensic physicians from the PHS IJsselland were excluded from participation to prevent bias.

The number of years of experience in forensic medicine influences the scoring of decomposition. ${ }^{40}$ To analyze whether the participants' experience also influences their estimation of the PMI, all participants were asked to write down their number of years of experience as a forensic physician. Not every participant complied $(n=7)$ and they were excluded from the experience analysis.

\subsection{Selection of cases}

Photographs from external postmortem investigations conducted by the Public Health Service (PHS) IJsselland were used. In the period from January 2001 to January 2016, a total of 1534 external postmortem investigations were carried out by this PHS.

To be included in this study, the cases had to be closed, meaning that no (criminal) case was still pending, in order to prevent interference with the juridical system. Identification had to have taken place and a report of the external postmortem investigation had to be available. Only bodies that were intact, fully photographed with face, torso and limbs visible and that were found indoors were included. Cases that involved bodies in an advanced state of decomposition were included (Gelderman's validated TDS $\geq 9$, scored by the researcher) ${ }^{29}$ because in practice the PMI is most difficult to assess in these cases. Cases concerning children, bodies found in water, burned bodies and completely skeletonized human remains were excluded.

The true PMI in these 15 cases was unknown. When human remains are found at home, it is not always possible to determine the PMI and as a result the date of death remains unknown. In addition, it was not possible to investigate the accuracy of these estimations.

There were 45 cases that met the inclusion criteria. Cases with unclear photographs $(n=7)$, injuries $(n=4)$ and poor composition of the photographs $(n=7)$ were excluded. Hereafter, 20 cases had a TDS 9, 1 case had a TDS of 10,1 case a TDS of 11 and 5 cases a TDS of 12 . In order to have sufficient variance in decomposition stages, the cases with a TDS of 10-12 were included. Of the 20 cases with a TDS of 9, the eight cases with the best composition of photographs were included.

Photographs of four cases showed the human remains at the location where it was found (at home). The other 11 cases were photographed at the morgue during the external inspection. Each case contained one to three photographs. Each photograph was detailed enough to be able to see the skin blisters, epidermolysis or skin discolorations if present. Four bodies were clad in a sweater/shirt, in three cases the trunk was (partially) not visible, and in one case the chest was not visible.

\subsection{Test situation}

The photographs were shown in a fixed order (because there were multiple photographs per case) via a PowerPoint presentation on a large screen. The 15 cases were put in the following order (which was unknown to the forensic physicians); cases 1-8 have a TDS of 9, case nine has a TDS of 10, case ten has a TDS of 11 and cases 11-15 had a TDS of 12. All bodies were found indoors and five bodies were found in the summer, five in the autumn, four in the spring and one in the winter. The meteorological seasons were used. The ambient temperature was mostly unknown in the reports.

The PMI was subdivided into ten categories (Table 1) for both statistical purposes and the fact that, after a period of time, the PMI often cannot be pinned down to one or a few days. The number of days increases with the ascending categories. This increasing time period has 
Table 1

PMI categories.

\begin{tabular}{ll}
\hline Category 1 & PMI 1-5 days \\
Category 2 & PMI 6-10 days \\
Category 3 & PMI 11-15 days \\
Category 4 & PMI 16-20 days \\
Category 5 & PMI 21-30 days \\
Category 6 & PMI 31-40 days \\
Category 7 & PMI 41-50 days \\
Category 8 & PMI 51-60 days \\
Category 9 & PMI 61-80 days \\
Category 10 & PMI $81-100$ days or more
\end{tabular}

been chosen because in initial stages daily changes in decomposition phenomena are visible, whereas in later stages visible changes take longer. ${ }^{4}$

Each forensic physician was asked to write down the PMI category (Table 1) corresponding with their PMI estimations, without consulting a colleague. The form was simple and consisted of a table including the 15 cases, the season the body was found in, a place to write down the category and the explanation of the categories.

The estimation is based on decomposition phenomena that were visible in photographs, additional information about the season in which each body was found and the fact that the bodies were found indoors. The forensic physicians did not use a decomposition scoring method (like Megyesi or Gelderman), instead their PMI estimation was based solely on their experience in estimating the PMI.

\subsection{Statistical analysis}

The inter-rater agreement between forensic physicians was calculated using the interclass correlation (ICC) test (two-way random effects, absolute agreement, single measurements) ${ }^{41}$ using SPSS version $24 .{ }^{41,42}$

The ICC test gives a correlation score between 0 and 1 . The scores are divided as follows: $0-0.40,0.40-0.59,0.60-0.74$ and $0.75-1$, which means a poor, fair, good and excellent correlation respectively. ${ }^{43}$ The ICC score was calculated for all 15 cases for which the 89 forensic physicians estimated the PMI.

The bivariate Spearman rank correlation was used to analyze the correlation between the number of years of experience and the PMI estimations. This correlation coefficient can take a value between -1 and 1 . The sign indicates the direction of the relationship. Values close to zero indicate a weak relationship. The closer the $r$-value gets to 1 (or
-1), the stronger the connection becomes. ${ }^{44}$

The ICC was also calculated for all the participants with a known number of years of experience by dividing the number of years of experience into five categories. The categories 1 to 5 are respectively: 1 (all cases), 2 ( $\leq 2$ years), 3 ( $3-5$ years), 4 (6-10 years) and 5 ( $>10$ years).

\subsection{Ethics and legal}

This research was conducted at the PHS IJsselland. This study was approved by the PHS IJsselland and performed according to the ethical and legal standards in the Netherlands. All data were processed anonymously. For this type of study, formal consent is not required.

\section{Results}

The overall ICC, using all the estimated PMI categories by the 89 forensic physicians and not corrected for the years of experience, is 0.254 (95\% CI $0.168,0.355$ ), which means that there is a poor correlation between the PMI estimations of the 89 forensic physicians for the selected fifteen cases.

Because only one case was in the winter, no ICC could be calculated for this season. The ICC for the summer $(n=5)$, autumn $(n=5)$ and spring $(\mathrm{n}=4)$ is respectively: $0.257 ; 95 \%$ CI [0.130, 0.394], 0.346; $95 \%$ CI $[0.213,0.480]$ and $0.192 ; 95 \%$ CI $[0.025,0.379]$. Since there are a very small number of cases per season, no statement could be made about the significance.

The box plot (Fig. 1) shows the spread of the PMI estimations per case. The cases are arranged according to the TDS. The box plot shows that the spread is relatively large for all cases.

Case number 10 has the most widespread estimations. Seventy-five percent of the participants estimated the PMI between score 4 and 7, while the other $25 \%$ estimated the PMI outside score 4 and 7 using all categories.

Case number 1 has the least widespread estimations; 75\% of the participants estimated the PMI between score 2 and 3, and 25\% scored category 1 and 4 .

There are also cases in which some forensic physicians scored outside the $75 \%$ and outside $Q_{1}-1.5 * \mathrm{IQ}$ (interquartile distance), the socalled outliers. These cases are 1, 3, 4, 5, 9 and 11-13.

Fig. 1 shows that despite the large spread, not all intermediate categories were chosen in a in each case. For example, case number 5 shows a spread of 1-80 days (score 1-9), but category 8 (51-60 days)

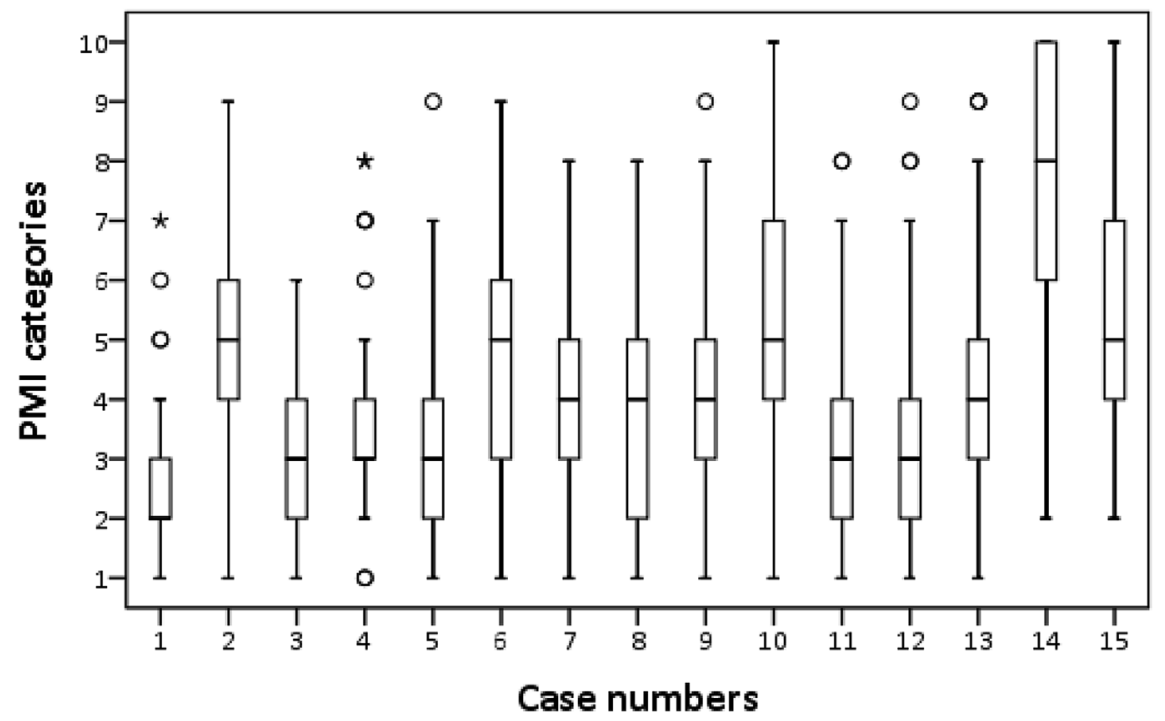

Fig. 1. Box plot, PMI estimations based on 89 forensic physicians for 15 cases. 
Table 2

Number of participants in experience categoriesICC $=$ interclass correlation. $\mathrm{CI}=$ confidence interval.

\begin{tabular}{llllll}
\hline Category & 1 & 2 & 3 & 4 & 5 \\
\cline { 2 - 6 } & All cases & $\begin{array}{c}<2 \\
\text { years }\end{array}$ & $3-5$ years & $6-10$ years & $>10$ years \\
& & & & & \\
\hline Number & 82 & 1 & 10 & 11 & 60 \\
ICC & 0.000 & & 0.147 & 0.372 & 0.227 \\
CI & -0.027, & & $0.051,0.404$ & $0.189,0.666$ & $0.143,0.337$ \\
& 0.029 & & & & \\
\hline
\end{tabular}

ICC = interclass correlation. $\mathrm{CI}=$ confidence interval.

was not selected by the forensic physicians.

The bivariate Spearman rank correlation between the experience and the PMI estimation was not found to be significant: $r=-0.007$, $p>0.05(p=0.402)$.

Since category 2 (years of experience $<2$ years) only contains one participant, the corresponding ICC could not be calculated. The other ICC outcomes for the other forensic physicians with a known amount of experience and per experience category are shown in Table 2 . The results show that the inter-rater agreement between the experienced forensic physicians is slightly better than the agreement between the less experienced forensic physicians. The CI shows that the differences between the correlations of the less experienced forensic physicians and the more experienced forensic physicians are not significant.

\section{Discussion}

In the Netherlands, the doctor has to estimate the time of death at the scene. In hospitals, the time of death is more reliable, since there is staff checking the patient regularly. When a person is found at home, it is more difficult for the general practitioner to estimate the time of death. Compared to forensic physicians, general practitioners are less educated concerning this task and must carry out this task less frequently. Most general practitioners in the Netherlands contact the forensic physician when a person is further along in the decomposition process. This research focused on forensic physicians and their duty to make a reliable estimation of the postmortem interval.

The ICC shows a poor agreement between the 89 forensic physicians and their PMI estimations, using no decomposition scoring method but only their experience with estimating the PMI as is the common procedure in the Dutch juridical system. The results of this study show that less experienced forensic physicians have a poorer inter-rater agreement than more experienced forensic physicians, but this difference is not significant. New and follow-up training could possibly improve the inter-rater agreement.

There are multiple interpretations of the ICC. The one frequently used is the interpretation made by Landis and Koch in which $<0,0-20$, $21-40,41-60,61-80,>81$ means poor, slight, fair, moderate, substantial and almost perfect agreement. ${ }^{45}$ Using this interpretation, it means that the overall ICC is a fair agreement instead of a poor agreement.

With the exception of our pilot, to our knowledge, there is only one similar study. Aydin et al. researched the consistency of the PMI estimations between forensic medicine assistants and specialists and an autopsy team. They described the stage of decomposition of the bodies but there were no photographs. The agreement between the participants and the autopsy team exceeded $50 \%$ in only 6 of the 25 cases. ${ }^{46}$ Aydin's study as well as our own raises the question of whether the agreement between the forensic physicians would increase if they scored the decomposition before estimating the PMI. It is also questionable whether the use of photographs is appropriate. Nawrocka et al. ${ }^{47}$ carried out a study using pigs that shows that the use of photographs that show multiple decomposition stages during the external examination results in a greater spread in the scoring of the decomposition phenomena. Many studies use photographs to score decomposition. An important reason for this is that real-time human remains are mostly unavailable. A recent study published by Ribéreau-Gayon et $a{ }^{48}$ investigates whether the use of photographs gives similar decomposition scoring results as scoring real time remains of pigs. A significant difference was found between real-time scores and photograph scores when using Megyesi's method. ${ }^{2,48}$ The authors reason that this is probably due to the fact that Megyesi's method was made for human remains and not pigs. Keough's method, ${ }^{49}$ which was developed for pig remains, showed no significant differences between real-time and photograph scores. It should be mentioned that these studies measure the decomposition and do not estimate the PMI based on the physician's experience.

Dabbs et al. $^{40}$ found that the years of experience in forensic medicine influences physicians' scoring of decomposition using Megyesi's TBS method. The influence of years of experience on estimating the PMI without using any decomposition scoring method, as examined in our study, was not part of Dabbs et al.'s research.

In the Netherlands, little research has been conducted on the factors (e.g., bodyweight, insect activity and temperature) that influence decomposition and thus the PMI estimations. Research is mostly carried out on pigs because pigs are considered to be suitable models since their skin and gut fauna are similar to those of human and they are relatively hairless. ${ }^{50}$ However, a recently published study by Keough et al. ${ }^{49}$ mentions that taphonomic research using pigs only seems valuable for studying variables that influence decomposition and the conclusions of such research cannot be directly applied for estimating the PMI in humans.

In contrast to the Netherlands, the United States has been carrying out taphonomic studies with human remains since 1972. However, these results are not representative in Dutch case studies because of the climate difference. ${ }^{1,51}$ This difference can be overcome by using the ADD. Recently, permission was received to set up a taphonomic research site using human bodies in the Netherlands.

Follow-up research could be conducted using cases with a known and large PMI, so that not only the precision of the estimation can be measured but also the accuracy. Moreover, follow-up research could take into account not only the season as an influencing factor but also other factors, such as clothing, insect activity and the location of the body inside a building (next to a heater, beneath a window etc.). Cases in the first stages of decomposition could also be included. The ICC would most likely be higher when 'fresh' bodies are included because the PMI category would probably range between 1 and 2. Since such bodies were not included in this research, the results of this research do not apply to such cases.

\subsection{Limitations}

Only bodies that were found indoors were included, since these cases are more common and because there are more factors outdoors that can influence the decomposition process, ${ }^{52,53}$ for example burial. ${ }^{19,25,54}$

It was decided to use photographs instead of observation in situ. The use of photographs made it possible for a number of cases to be estimated regarding the PMI by a large number of participants. The use of photographs also allowed cases from 2001 to 2016 to be included, making the research more extensive than would be possible with in situ observation. However, the use of photographs also has several limitations. Due to covering, such as clothing, some body parts were less visible than others in the photographs. Because of this, it could not be determined whether the non-visible part showed different decomposition phenomena than the visible part. ${ }^{47,55}$ Furthermore, the use of photographs meant information obtainable through scent and palpation could not be used to estimate the PMI.

The classification and life stages of maggots and insects were also 
difficult to see on the photographs. However, this mainly affects the accuracy of the estimations, which was not part of the current study. Finally, although all participants were presented with the same visual material, they viewed this material using different screens. Thus, it is possible that screen size, lighting and color differences influenced their perception of the photographs.

\section{Conclusion}

There is poor agreement between forensic physicians with regard to their PMI estimations while using their experience. Therefore, it is not advisable to use these estimations in Dutch court.

\section{Declarations of interest}

None.

\section{Funding}

This research did not receive any specific grant from funding agencies in the public, commercial, or not-for-profit sectors.

\section{Acknowledgements}

We would like to thank all the forensic physicians who participated in this study. This research could not have been conducted without your help. This research was presented via an e-poster at the EAFS 2018 congress (number P0260).

\section{Appendix A. Supplementary data}

Supplementary data to this article can be found online at https:// doi.org/10.1016/j.jflm.2018.12.004.

\section{References}

1. Suckling JK, Spradley MK, Godde K. A longitudinal study on human outdoor decomposition in central Texas. J Forensic Sci. 2016;61(1):19-25.

2. Megyesi M, Nawrocka S, Haskell N. Using accumulated degree-days to estimate the postmortem interval from decomposed human remains. J Forensic Sci. 2005;50(3):618-626.

3. Galloway A, Birkby WH, Jones AM, Henry TE, Parks BO. Decay rates of human remains in an arid environment. J Forensic Sci. 1989;34(3):607-616.

4. Madea B, Henssge C, Reibe S, Tsokos M, Kernbach-Wighton G. Postmortem changes and time since death. In: Madea B, ed. Handbook of Forensic Medicine. Hoboken, NJ: Wiley-Blackwell; 2014:75-133.

5. Gunn A. Essential Forensic Biology. second ed. Hoboken, NJ: Wiley-Blackwell; 2009.

6. Zhou C, Byard RW. Factors and processes causing accelerated decomposition in human cadavers - an overview. J Forensic Leg Med. 2011;18(1):6-9.

7. Campobasso CP, Di Vella G, Introna F. Factors affecting decomposition and Diptera colonization. Forensic Sci Int. 2001;120:18-27.

8. Cross P, Simmons T. The influence of penetrative trauma on the rate of decomposition. J Forensic Sci. 2010;55(2):295-301.

9. Dautartas AM. The Effect of Various Coverings on the Rate of Human Decomposition Master's Thesis University of Tennessee; 2009.

10. Mann RW, Bass WM, Meadows L. Time since death and decomposition of the human body: variable and observations in case and experimental field studies. J Forensic Sci. 1990;35(1):103-111.

11. Matuszewski S, Konwerski S, Frątczak K, Szafalowicz M. Effect of body mass and clothing on decomposition of pig carcasses. Int J Leg Med. 2014;128:1039-1048.

12. Sutherland A, Myburgh J, Steyn M, Becker PJ. The effect of body size on the rate of decomposition in a temperate region of South Africa. Forensic Sci Int. 2013;31(1 3):257-262.

13. Spicka A, Johnson R, Bushing J, Higley LG, Carter DO. Carcass mass can influence rate of decomposition and release of ninhydrin-reactive nitrogen into gravesoil. Forensic Sci Int. 2011;209(1-3):80-85

14. Simmons T, Adlam RE, Moffat C. Debugging decomposition data-comparative taphonomic studies and the influence of insects and carcass size on decomposition rate. J Forensic Sci. 2010;55(1):8-13.

15. Pakosh CM, Rogers TL. Soft tissue decomposition of submerged, dismembered pig limbs enclosed in plastic bags. J Forensic Sci. 2009;54(6):1223-1228.

16. Kelly JA, van der Linde TC, Anderson GS. The influence of clothing and wrapping on carcass decomposition and arthropod succession during the warmer seasons in central South Africa. J Forensic Sci. 2009;54(5):1105-1112.

17. Turner B, Wiltshire P. Experimental validation of forensic evidence: a study of the decomposition of buried pigs in a heavy clay soil. Forensic Sci Int. 1999;26(2):113-122 101.

18. Tumer AR, Karacaoglu E, Namli A, et al. Effects of different types of soil on decomposition: an experimental study. Leg Med. 2013;15(3):149-156.

19. Troutman L, Moffatt C, Simmons T. A preliminary examination of differential decomposition patterns in mass graves. J Forensic Sci. 2014:59(3):621-626.

20. Kunz SN, Brandtner H, Meyer H. Putrefaction in a mortuary cold room? Unusual progression of postmortem decomposition processes. Arch Kriminol. 2013;231:130-135.

21. Henssge C. Death time estimation in case work I The rectal temperature time of death nomogram. Forensic Sci Int. 1988;38(3-4):209-236.

22. Henssge C, Madea B. Estimation of the time since death in the early post-mortem period. Forensic Sci Int. 2004;144(2-3):167-175.

23. Hubiga M, Muggenthalera H, Sinicina I, Malla G. Temperature based forensic death time estimation: the standard model in experimental test. Leg Med. 2016;17(5):381-387

24. Warther S, Sehner S, Raupach T, Püschel K, Anders S. Estimation of the time since death: post-mortem contractions of human skeletal muscles following mechanical stimulation (idiomuscular contraction). Int J Leg Med. 2012;126:399-405.

25. Cockle D, Bell L. Human decomposition and the reliability of a "Universal" model for post mortem interval estimations. Forensic Sci Int. 2015;253 136.e1-9.

26. Maile AE, Inoue CG, Barksdale LE, Carter DO. Toward a universal equation to estimate postmortem interval, Forensic Sci Int 2017:272:150-153.

27. Zilg B, Bernard S, Alkass K, Berg S, Druida H. A new model for the estimation of time of death from vitreous potassium levels corrected for age and temperature. Forensic Sci Int. 2015;254:158-166.

28. Rognum TO, Holmen S, Musse MA, et al. Estimation of time since death by vitreous humor hypoxanthine, potassium, and ambient temperature. Forensic Sci Int. 2016;262:160-165.

29. Gelderman HT, Boer L, Naujocks T, IJzermans ACM, Duijst WLJM. The development of a post-mortem interval estimation for human remains found on land in The Netherlands. Int J Leg Med. 2018;132(3):863-873.

30. Sharma R, Garg RK, Gaur JR. Various methods for the estimation of the post mortem interval from Calliphoridae: a review. Egypt J Forensic Sci. 2015;5(1):1-12.

31. Arnaldos MI, García MD, Romera E, Presa JJ, Luna A. Estimation of postmortem interval in real cases based on experimentally obtained entomological evidence. Forensic Sci Int. 2005;149(1):57-65.

32. Charabidze D, Colard T, Vincent B, Pasquerault T, Hedouin V. Involvement of larder beetles (Coleoptera: dermestidae) on human cadavers: a review of 81 forensic cases. Int J Leg Med. 2014;128(6):1021-1030.

33. Vass AA, Bass WM, Wolt JD, Foss JE, Ammons JT. Time since death determinations of human cadavers using soil solution. J Forensic Sci. 1992;37(5):1236-1253.

34. Fancher JP, Aitkenhead-Peterson JA, Farris T, et al. An evaluation of soil chemistry in human cadaver decomposition islands: potential for estimating postmortem interval (PMI). Forensic Sci Int. 2017;279:130-139.

35. Mao S, Fu G, Seese RR, Wang ZY. Estimation of PMI depends on the changes in ATP and its degradation products. Leg Med. 2013;15(5):235-238.

36. Sun TY, Zhang HD, Yang TT, Liu L. Changes in ATP levels in rabbit blood and its application for estimation of the postmortem interval. J Huazhong Univ Sci Technolog Med Sci. 2013;33(3):452-456.

37. Liu Q, Sun Q, Liu L, Zhou L, Zheng N, Liu L. Bioluminescent assay of microbial ATP in postmortem tissues for the estimation of postmortem interval. $J$ Huazhong Univ Sci Technolog Med Sci. 2009;29(6):679-683

38. Krap T, Duijst W. De postmortale tijdsbepaling als bewijsmiddel (The determination of the postmortem interval as evidence). Expertise en Recht. 2015-1:19-25.

39. Gelderman T, Krap T, Duijst W. Het bepalen van het tijdstip van overlijden gebaseerd op ontbinding (The estimation of the post-mortem interval based on decomposition). Expertise en Recht. 2017;4:155-158.

40. Dabbs GR, Connor M, Bytheway JA. Interobserver reliability of the total body score system for quantifying human decomposition. J Forensic Sci. 2016;61(2):445-451.

41. Koo TK, Li MY. A guideline of selecting and reporting intraclass correlation coefficients for reliability research. J Chiropr Med. 2016;15(2):155-163.

42. Kim HY. Statistical notes for clinical researchers: evaluation of measurement error 1 : using intraclass correlation coefficients. Restor Dent Endod. 2013;38(2):98-102.

43. Cicchetti DV. Guidelines, criteria, and rules of thumb for evaluating normed and standardized assessment instruments in psychology. Psychol Assess. 1994;6(4):284

44. Mukaka MM. A guide to appropriate use of Correlation coefficient in medical research. Malawi Med J. 2012;24(3):69-71.

45. Landis JR, Koch GG. The measurement of observer agreement for categorical data. Biometrics. 1977;33:159-174.

46. Aydin B, Çolak B, Balci Y, Demirüstü C. Consistency of postmortem interval estimations of physicians using only postmortem changes of putrefied dead bodies. Am J Forensic Med Pathol 2010:31:243-246.

47. Nawrocka M, Frątczak K, Matuszewski S. Inter-rater reliability of total body score-A scale for quantification of corpse decomposition. J Forensic Sci. 2016;61(3):798-802.

48. Ribéreau-Gayon A, Rando C, Morgan RM, Carter DO. The suitability of visual taphonomic methods for digital photographs: an experimental approach with pig carcasses in a tropical climate. Sci Justice. 2018;58(3):167-176.

49. Keough N, Myburgh J, Steyn M. Scoring of decomposition: a proposed amendment to the method when using a pig model for human studies. J Forensic Sci. 2017;62(4):986-993.

50. Anderson GS, VanLaerhoven SL. Initial studies on insect succession on carrion in southwestern British columbia. J Forensic Sci. 1996;41(4):617-625.

51. Cockle DL, Bell LS. The environmental variables that impact human decomposition in terrestrially exposed contexts within Canada. Sci Justice. 2017;57(2):107-117.

52. Bass WM Outdoor decomposition rates in Tennessee. In: Haglund WD, Sorg MH, eds. 
Forensic Taphonomy: The Postmortem Fate of Human Remains. New York, NY: CRC Press; 1997:181-186.

53. Anderson GS. Comparison of decomposition rates and faunal colonization of Carrion in indoor and outdoor environments. J Forensic Sci. 2011;56(1):136-142.

54. Marais-Werner A, Myburgh J, Becker PJ, Steyn M. A comparison between decomposition rates of buried and surface remains in a temperate region of South Africa. Int J Leg Med. 2018;132(1):301-309.

55. Dabbs GR, Bytheway JA, Connor M. Comparing the scoring of human decomposition from digital images to scoring using on-site observations. J Forensic Sci. 2017;62(5):1292-1296. 